Vol.46, n. 4 : pp. 521-527, December 2003 ISSN 1516-8913 Printed in Brazil

AN INTERNATIONAL JOURNAL

\title{
Genetic Diversity in Passion Fruit (Passiflora spp.) Evaluated by RAPD Markers
}

\author{
Maria Lúcia Crochemore* , Hugo Bruno Correa Molinari and Luiz Gonzaga Esteves Vieira \\ Laboratório de Biotecnologia; Instituto Agronômico do Paraná (IAPAR); C. P. 481; 86001-970; Londrina - PR - \\ Brazil
}

\begin{abstract}
The objective of this study was to characterize the genetic diversity within a Passiflora collection by PCR-RAPD markers. Genetic analysis was performed in 70 accessions, representing 11 species of the genus Passiflora. The use of only five primers produced 136 reproducible polymorphic bands. The hierarchical classification showed high levels of dissimilarities between and within the species studied. A clear separation was obtained among species and accessions of $P$. edulis and $P$. edulis $f$. flavicarpa, which were forms of the high commercial value species. The fingerprints produced from the studied genotypes would allow the identification of improved varieties/populations in an easy, fast and inexpensive manner.
\end{abstract}

Key words: Passiflora spp., germoplasm, genetic diversity, RAPD-PCR

\section{INTRODUCTION}

Passiflora is the most important genus in the family Passifloriaceae and it is distributed within tropical and sub-tropical regions. Approximately, 460 species of the genus Passiflora have already been described. From these, about $90 \%$ have originated from the Americas and close to 150 species occur in Brazil (Sousa and Meletti, 1997). The economical importance of some species is associated to the quality of the fruits for consumption and medicinal properties.

The passion fruit is an allogamous plant and the edible fruit-producing species are diploids $(2 \mathrm{n}=18)$, namely, the purple ( $P$. edulis) and the yellow passion fruit ( $P$. edulis f. flavicarpa) (Martin and Nakasone, 1970), which is cultivated in Brazil. The high interspecific compatibility in natural and artificial crossings among the diploid species leads to a wide genetic diversity distributed in different agro-climatic regions. Morphological characters used for taxonomical description of passion fruit have allowed a classification up to the species level, but not to an intraspecific discrimination. Besides fruit color, flavor and resistance to diseases, $P$. edulis and $P$. edulis f. flavicarpa do not show contrasting differences (Martin and Nakasone, 1970). Although still not much used in passion fruit genetic variability studies, RAPD markers have been shown to be polymorphic, allowing the characterization of the variability among and within species as well as for the identification of hybrids and parentals (Fajardo et al., 1998, Cassiano, 1998; Otoni et al., 1995). The characterization of the genetic diversity within a Brazilian Passiflora spp. collection using RAPD markers may permit the discrimination of plant introductions, the analysis of inter- and intraspecific variability and the detection of

\footnotetext{
* Author for correspondence
} 
duplicated accessions resulting in a complementary tool for selection of progenitors for breeding programs. Also, the identification of cultivars, which are forms of the high commercial value species by molecular markers, may be a valuable support in view of Cultivar Protection Laws (Jondle, 1992). Although these molecular descriptors are not accepted for protecting intellectual property by the UPOV convention (International Union for the Protection of New Varieties of Plants), these techniques have an enormous potential for cultivars discrimination and deserve further investigation. The objective of this study was to characterize the genetic diversity within a Passiflora collection by RAPD markers.

Table 1 - Codes, species and origin of the Passiflora spp. germplasm collection maintained at IAPAR.

\begin{tabular}{|c|c|c|c|c|c|}
\hline Code & Species & Origin & Code & Species & Origin \\
\hline LM 1 & P. edulis f. flavicarpa & Brazil - SP & IA 83 & P. edulis f. flavicarpa & Brazil - MG \\
\hline LM 2 & P. edulis f. flavicarpa & Brazil - SP & IA 81 & P. edulis f. flavicarpa & Brazil - MG \\
\hline LM 3 & P. edulis f. flavicarpa & Brazil - SP & IA 80 & P. edulis f. flavicarpa & Brazil - MG \\
\hline LM 4 & P. edulis f. flavicarpa & Brazil - PR & IA 65 & P. edulis f. flavicarpa & Brazil - MG \\
\hline LM 5 & P. edulis f. flavicarpa & Brazil - PR & IA52 & P. edulis f. flavicarpa & Brazil - ES \\
\hline LM 6 & P. edulis f. flavicarpa & Brazil - PR & IA 48 & P. edulis f. flavicarpa & Brazil - PR \\
\hline LM 7 & P. edulis f. flavicarpa & Brazil - MG & IA 47 & P. edulis f. flavicarpa & Brazil - MG \\
\hline LM 8 & P. edulis f. flavicarpa & Brazil - PR & IA 46 & P. edulis f. flavicarpa & Brazil - PR \\
\hline LM 9 & P. edulis f. flavicarpa & Brazil - PR & IA 42 & P. edulis f. flavicarpa & Brazil - MG \\
\hline LM 10 & P. edulis f. flavicarpa & Brazil - PR & IA 33 & P. edulis f. flavicarpa & Brazil - SP \\
\hline BG 15 & Passiflora coccinea & Brazil - AM & IA 31 & P. edulis f. flavicarpa & Brazil - MG \\
\hline BG 01 & Passiflora macrocarpa & Brazil - SP & IA 30 & P. edulis f. flavicarpa & Brazil - SP \\
\hline BG 10 & Passiflora caerulea & Brazil - SP & IA 27 & P. edulis f. flavicarpa & Brazil - SP \\
\hline BG 11 & Passiflora suberosa & Brazil - SP & IA 25 & P. edulis f. flavicarpa & Brazil - SP \\
\hline BG 17 & Passiflora giberti & Brazil - SP & IA 24 & P. edulis f. flavicarpa & Brazil - PR \\
\hline BG 08 & P. serrato digitata & Brazil - SP & IA 14 & P. edulis f. flavicarpa & Brazil - ES \\
\hline BG 04 & Passiflora edulis & Kenya & IA 10 & P. edulis f. flavicarpa & Brazil - PR \\
\hline BG 26 & Passiflora edulis & Chile & IA 28 & P. edulis f. flavicarpa & Brazil - PR \\
\hline BG 19 & Passiflora edulis & Madeira Island & IA 59 & P. edulis f. flavicarpa & Brazil - PR \\
\hline BG 21 & Passiflora edulis & Brazil - PR & IA $58 \mathrm{a}$ & P. edulis f. flavicarpa & Brazil - ES \\
\hline BG 24 & Passiflora foetida & Brazil - RJ & IA 12 & P. edulis f. flavicarpa & Brazil - MG \\
\hline BG 20 & Passiflora edulis & Morocco & IA 60 & P. edulis f. flavicarpa & Brazil - MG \\
\hline BG 18 & P. edulis $\times$ P. edulis f. flavicarpa & Brazil - SP & IA 45 & P. edulis f. flavicarpa & Brazil - PR \\
\hline BG 06 & Passiflora alata & Brazil & IA 43 & P. edulis f. flavicarpa & Brazil - SP \\
\hline BG 02 & Passiflora edulis & Brazil - MG & IA 91 & P. edulis f. flavicarpa & Brazil - MG \\
\hline BG 16 & Passiflora edulis & Australia & IA 29 & P. edulis f. flavicarpa & Brazil - SC \\
\hline BG 25 & Passiflora alata & Brazil & IA 20 & P. edulis f. flavicarpa & Brazil - PR \\
\hline BG 05 & P. alata $\times$ P. macrocarpa & Brazil - SP & IA 49 & P. edulis f. flavicarpa & Brazil - ES \\
\hline BG 09 & Passiflora edulis & Brazil - SP & IA 71 & P. edulis f. flavicarpa & Brazil - PR \\
\hline BG 23 & Passiflora edulis & Brazil - SP & IA 54 & P. edulis f. flavicarpa & Brazil - PR \\
\hline BG 27 & Passiflora alata & Peru & IA 37 & P. edulis f. flavicarpa & Brazil - PR \\
\hline BG 34 & Passiflora sp. (1) & ----- & IA 86 & P. edulis f. flavicarpa & Brazil - MG \\
\hline BG 14 & Passiflora edulis & Brazil - SP & IA 11 & P. edulis f. flavicarpa & Brazil - ES \\
\hline BG 35 & Passiflora sp. (2) & ----- & IA $58 \mathrm{~b}$ & P. edulis f. flavicarpa & Brazil - ES \\
\hline IA 87 & P. edulis f. flavicarpa & Brazil - MG & IA 62 & P. edulis f. flavicarpa & Brazil - SC \\
\hline
\end{tabular}

\section{MATERIALS AND METHODS}

\section{Plant Material}

Seventy introductions of the IAPAR's Passiflora spp. Germplasm Collection, comprising 11 species and two not-classified introductions were used. Their origin and identification are shown in
Table 1. Seedlings propagated by budding or grafting were grown under greenhouse facilities.

\section{DNA extraction}

Young leaf tissues $(30-40 \mathrm{mg})$ from each introduction were harvested at the same plant growth stage. The leaves were oven-dried $\left(37^{\circ} \mathrm{C}\right)$ for $12 \mathrm{~h}$ and then macerated until a fine dust. DNA 
extraction was performed as described by Molinari and Crochemore (2001). DNA concentration was estimated in a fluorimeter as described by the manufacturer (Hoefer Scientific Instruments).

\section{RAPD analysis}

RAPD reactions were performed according to Williams et al. (1990) in a final volume of $25 \mu \mathrm{l}$ containing 25 ng genomic DNA, $2.5 \mu$ buffer $10 \mathrm{X}$ [200 mM Tris (pH 8.4), $500 \mathrm{mM} \mathrm{KCl})$, gelatin $0.01 \%, 1.5 \mathrm{mM} \mathrm{MgCl}, 0.25 \mathrm{mM}$ of each dNTP, $0.2 \mu \mathrm{M}$ primer and $1 \mathrm{U}$ Taq polymerase. The amplifications were performed in a thermocycler (MJ Research, Inc.) using the following program: 1 cycle of 4 min at $94^{\circ} \mathrm{C}$ followed by 37 cycles of
1 min at $93^{\circ} \mathrm{C}, 1 \min$ at $45^{\circ} \mathrm{C}$ and 1 min at $72^{\circ} \mathrm{C}$, with a final extension of $6 \mathrm{~min}$ at $72^{\circ} \mathrm{C}$.

Amplification products were analyzed by electrophoresis at $5 \mathrm{~V} / \mathrm{cm}$ in agarose gel $(1.4 \%)$. The gel was stained in $0.5 \mu \mathrm{g} / \mathrm{ml}$ ethidium bromide solution and photographed with the KODAK EDAS 120 system.

From a screening using 42 primers (Operon Technologies, Inc. Kits A, B, AE1 and C16 oligonucleotides), five primers were shown to be highly polymorphic and were used in this study (Table 2). Only amplified consistent DNA bands, in the approximate range of $0,1-3$ kilobases $(\mathrm{kb})$ were scored.

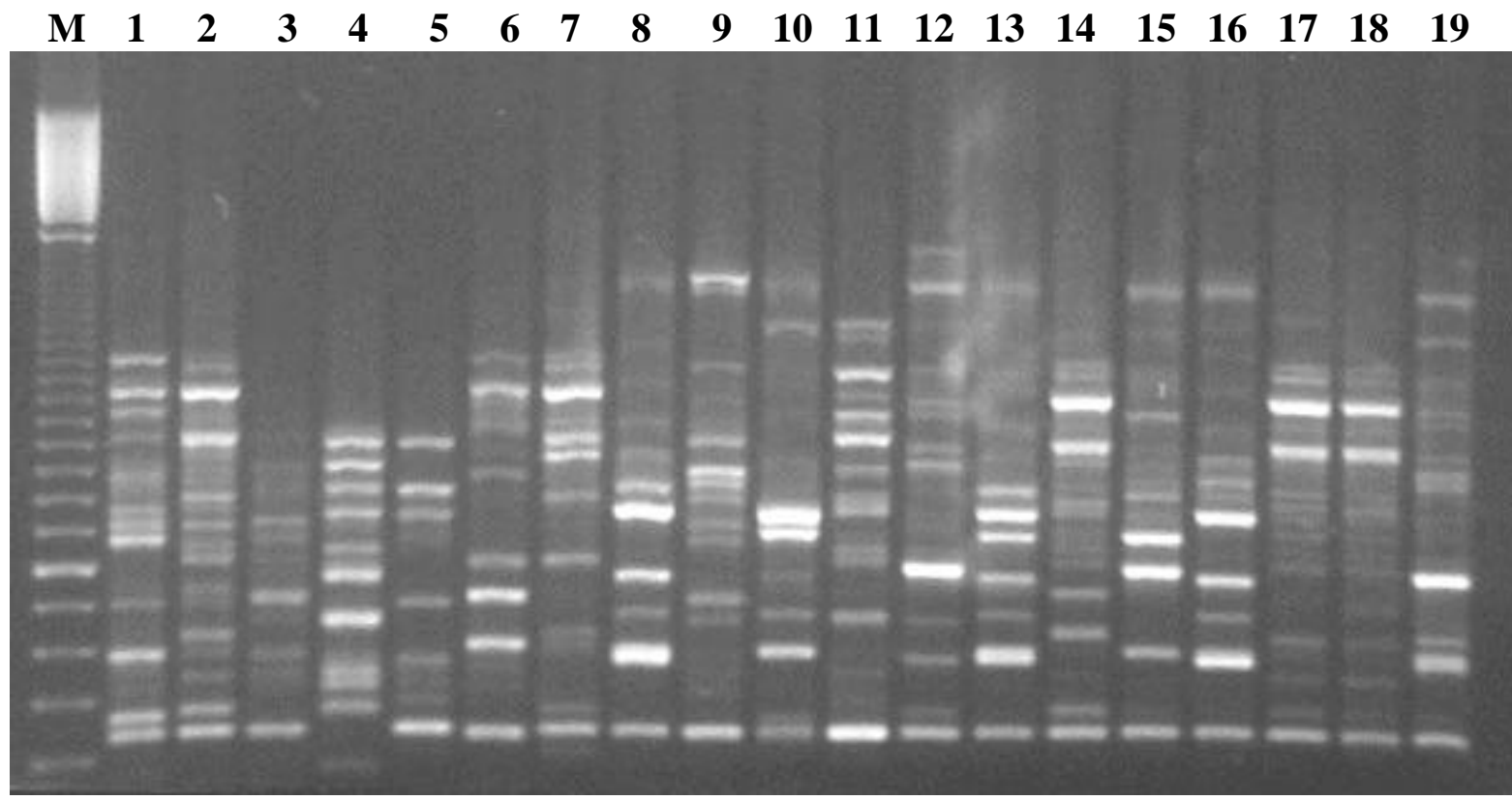

Figure 1 - Random amplified polymorphic DNA from 19 Passiflora spp. accessions using primer OPB-18. Lane M: 100 bp molecular weigth. Lane (1) P. coccinea, (2) P. macrocarpa, (3) P. caerulea, (4) P. suberosa, (5) P. giberti, (6) P. serrato digitata, (7) P. edulis (Kenya), (8) P. edulis (Chile), (9) P. edulis (Madeira Island), (10) P. edulis (Brazil, Parana state), (11) P. foetida, (12) P. edulis (Morocco), (13) P. edulis x P. edulis f. flavicarpa, (14) P. alata, (15) P. edulis (Brazil, Sao Paulo state), (16) P. edulis (Australia), (17) P. alata, (18) P. alata x P. macrocarpa, (19) P. edulis (Brazil, Sao Paulo state).

\section{Statistical analysis}

Jaccard's similarity indexes (Jaccard, 1901) were calculated with data provided by the observation of the presence (1) or absence (0) of bands between pairs of accessions using the formula $\mathrm{D}_{(\mathrm{ij})}$ $=a /(a+b+c)$, where: $\mathbf{a}$ is the number of fragments shared by accessions $\mathbf{i}$ and $\mathbf{j}$; $\mathbf{b}$ is the number of fragments present in $\mathbf{i}$ and absent in $\mathbf{j}$; $\mathbf{c}$ is the number of fragments present in $\mathbf{j}$ and absent in i. A hierarchical classification (dendrogram) was obtained from the similarity matrix using the UPGMA (Unweighted Pair Group Mathematical Average) method. The mean similarities and variances detected in the hierarchical classification were calculated. All calculations were performed 
using the SAS Statistical Program (SAS Institute, 1998).

\section{RESULTS AND DISCUSSION}

Table 2 summarizes the number, average and size range of amplified fragments obtained with the five primers used to compare the Passiflora collection. A total of 136 amplified fragments were selected. Depending on the introductionprimer combination, between 1 and 11 distinct RAPD products were amplified, ranging in size from approximately 120 to $3000 \mathrm{bp}$. Each RAPD amplification was prepared at least three times to determine reproducibility of the patterns.

\section{Genetic diversity}

High dissimilarity was observed among the introductions. The hierarchical classification obtained by the clustered method showed three large groups (Fig. 2). The values of mean dissimilarity, range and variances of all possible pairwise comparisons within these groups are shown on Table 3. As expected, the highest dissimilarity was observed among the species of Group I. This group is composed by 14 accessions, comprising the species: $P$. cocinea, $P$. alata, $P$. macrocarpa, $P$. edulis, $P$. alata $\times$ P. macrocarpa $P$. caerulea, $P$. serrato-digitata, $P$. giberti and $P$. suberosa, two accessions of $P$. edulis (Kenya and Madeira Island) and the accession Passiflora sp. (2). The lowest dissimilarity in Group I was found between accession BG25 (P. alata) and BG05
(P. alata $\times$ P. macrocarpa). On the other hand, the highest dissimilarity (0.97) was found between accession BG11 (P. suberosa) and BG23 ( $P$. edulis) from Group II.

Group II was exclusively formed by eight introductions of $P$. edulis, a cross between $P$. edulis and the introduction Passiflora sp. (1). This group showed a mean dissimilarity of 0.67 (Table 3). This high variation observed within P. edulis was corroborated by Cassiano (1998) but was not detected in the studies done by Fajardo et al. (1998) probably due to the small number of accessions studied by these authors. Two introductions, originally classified as $P$. edulis one from Kenya (BG04) and the other from Madeira Island (BG19) - were assigned to Group I. However, due to their close similarity to alatamacrocarpa and $P$. caerulea respectively, we inferred that these introductions were misclassified in the original germoplasm collection. The introduction named Passiflora sp. (1), was grouped very close to a wild Brazilian introduction $(d=0.56)$ of $P$. edulis, and probably it was closed related to this species.

Group III was formed by 46 introductions of $P$. edulis f. flavicarpa, native of several states of Brazil (Table 1). The LM introductions had been selected according to their desirable agronomical characteristics. On the other hand, IA introductions were introduced genotypes, without any specific selected characteristic. Despite being formed only by $P$. edulis f. flavicarpa, this group presented a mean dissimilarity of 0.40 (Table 3).

Table 2 - Summary of data obtained by RAPD analysis for 70 Passiflora spp. introductions

\begin{tabular}{l|c|c|c}
\hline \multicolumn{1}{c}{ Primer sequence } & $\begin{array}{c}\text { Number of } \\
\text { amplified } \\
\text { fragments }\end{array}$ & $\begin{array}{c}\text { Average amplified } \\
\text { fragments/plants } \\
\text { (range) }\end{array}$ & $\begin{array}{c}\text { Amplified fragment size } \\
\text { range (bp) }\end{array}$ \\
\hline OPA04 - AATCGGGCTG & 33 & $7.46(1-11)$ & $120-2000$ \\
OPB08 - GTCCACACGG & 26 & $4.91(1-8)$ & $350-2000$ \\
OPB18 - CCACAGCAGT & 29 & $6.84(2-10)$ & $350-2100$ \\
OPB19 - ACCCCCGAAG & 29 & $6.01(1-10)$ & $470-3000$ \\
OPB20 - GGACCCTTAC & 19 & $4.81(2-7)$ & $420-2000$ \\
Total & 136 & $6.00(1-11)$ & $120-3000$ \\
\hline
\end{tabular}


The grouping method (UPGMA) allowed a perfect distinction between the introductions LM and IA showing that the RAPD markers were useful even to discriminate closely related genotypes.

$P$. edulis f. flavicarpa was likely to be a population selected from $P$. edulis based on agronomical characteristics, like fruit color. The classification obtained evidences the genetic ascendancy of $P$. edulis over $P$. edulis f flavicarpa, supporting the origin of $P$. edulis f. flavicarpa as a mutation of $P$. edulis (Pope and Degener, cited by Martin and
Nakasone, 1970) and not from a cross of P. edulis with any of the species herein studied. Our results have shown that could be possible to distinguish several Passiflora species as well as separate accessions of $P$. edulis and $P$. edulis f. flavicarpa with only five primers. Molecular markers are very useful in an early breeding program for allowing germoplasm screening at any developmental stage of the plants or when a large number of individuals need to be evaluated.

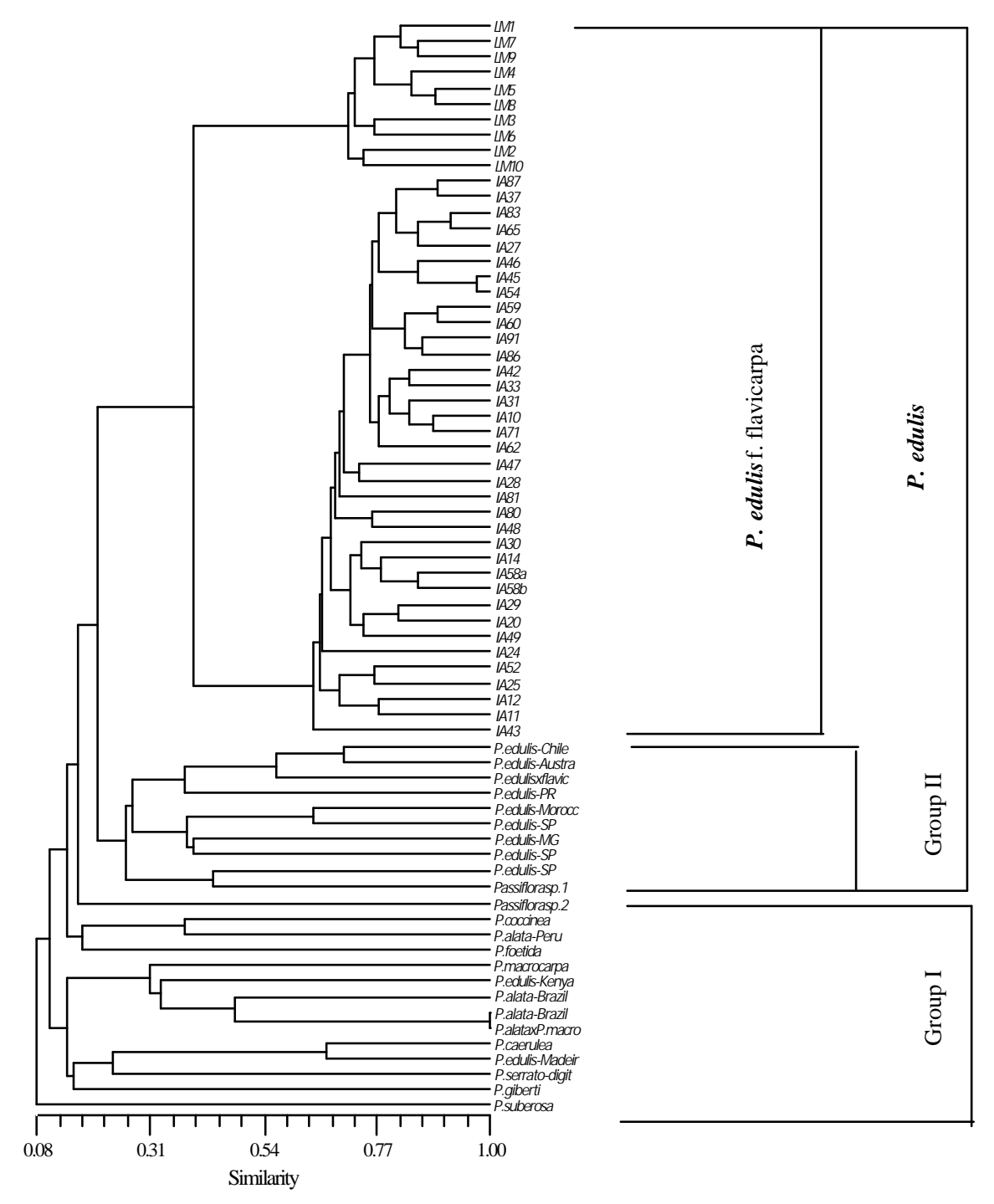

Figure 2 - Dendrogram showing the genetic relationships among 70 accessions representing 11 species of Passiflora clustered by UPGMA method based on bands generated using five primers. Scale value of 1 indicates $100 \%$ genetic similarity. 
Table 3 - Mean dissimilarities and variances within the three groups formed by 70 accessions of Passiflora spp. based on RAPD markers.

\begin{tabular}{lcccc}
\multicolumn{1}{c|}{ Group } & $\begin{array}{c}\text { Number } \\
\text { of introductions }\end{array}$ & $\begin{array}{c}\text { Mean } \\
\text { dissimilarity }\end{array}$ & Variance \\
\hline Group I - Passiflora sp. & 14 & 0,84 & 0,03 \\
Group II - P. edulis & 10 & 0,67 & 0,03 \\
Group III - P. edulis f. flavicarpa & 46 & 0,40 & 0,01 \\
Total & 70 & 0,64 & 0,07 \\
\hline
\end{tabular}

\section{Fingerprinting}

The analysis of the RAPD products profile showed highly discriminative amplified fragments among the 70 introductions studied. An example of banding patterns given by DNA amplification products after agarose gel electrophoresis is presented in Fig. 1.

The primer OPA-04 showed the highest discriminative power and could be used to clearly discriminate the group flavicarpa from all other accessions. This primer revealed a specific band (700 bp) for all accessions of $P$. alata and $P$. macrocarpa and it also identified $P$. foetida by a $640 \mathrm{bp}$ fragment. The primer OPB-08 separated $P$. edulis from $P$. edulis f. flavicarpa and also revealed one specific amplified fragment for Passiflora sp. (2) and one for P. coccinea. The lack of a OPB-18-440bp fragment, present in all introductions of the collection was characteristic for the $P$. suberosa. Moreover, three specific amplified fragments revealed with only primer OPB-18 were found in Passiflora sp. (2). The primer OPB-19 presented a specific amplified fragment (550bp) for $P$. giberti and the primer OPB-20 revealed four fragments that specifically discriminated Passiflora sp. (2) and P. giberti. Specific RAPD products were not found in $P$. caerulea, $P$. serrato-digitata and, therefore, it was not possible to discriminate these introductions from all others of the germoplasm collection.

\section{ACKNOWLEDGEMENTS}

We thank Neusa C. Stenzel from IAPAR for providing the germoplasm collection.

\section{RESUMO}

A diversidade genética de Passiflora spp. tem sido estudada basicamente através de características morfológicas e agronômicas, levando à uma classificação até espécie. A caracterização intraespecífica por meio destes descritores necessita de um ciclo integral de cultivo, e é pouco discriminante. $\mathrm{O}$ objetivo deste estudo foi caracterizar a variação genética de uma coleção de Passiflora através da técnica RAPD. Análises moleculares foram realizadas em 70 acessos, envolvendo 11 espécies do gênero Passiflora. A utlização de apenas cinco primers permitiu a obtenção de 136 fragmentos polimórficos. A classificação hierárquica obtida mostrou alto nível de dissimilaridade entre e dentro das espécies. Nítida separação foi obtida entre acessos de $P$. edulis e da forma flavicarpa, de alto interesse comercial, fracamente diferenciados pelas características morfológicas e agronômicas. A utilização desses marcadores na avaliação dos recursos genéticos de Passiflora, é atrativa para o melhorista e poderá muito auxiliar na identificação dos acessos, pela facilidade, rapidez e pelo baixo custo na condução das avaliações.

\section{REFERENCES}

Cassiano, A. P. A. A. (1998), Variações genéticas entre espécies de Passiflora (Passifloraceae) usando marcadores RAPD, Jaboticabal. Dissertação (Mestrado em Genética e Melhoramento de Plantas). 47 pp.

Fajardo, D.; Angel, F.; Grum, M.; Tohme, J.; Lobo, M.; Roca, W. M. and Sanchez, I. (1998), Genetic variation analysis of the genus Passiflora L. using RAPD markers. Euphytica, 101, 341-347.

Jaccard, P. (1991), Étude comparative de la distribution florale dans une portion des Alpes et des Jura. Bull. Soc. Vaudoise Sci. Nat., 37, 547-579.

Jondle, R. (1992), Legal aspects of varietal protection using molecular markers. In: Applications of RAPD technology to plant breeding. Joint plant breeding symposia series, Minnesota, USA. pp. 50-52.

Martin, F. W.; Nakasone, H. Y. (1970), The edible species of Passiflora. Economic Botanic, 24, 333-43. 
Molinari, H. B.; Crochemore, M. L. (2001), Extração de DNA genômico de Passiflora spp. para análises PCRRAPD. Rev. Bras. Frutic., 23 : (2), 447-450.

Otoni , W. C.; Blackhall, N. W.; D’utra Vaz, F. B.; Casali, V. W.; Power, J. B. and Davey, M. R. (1995), Somatic hybridization of the Passiflora species, $P$. edulis f. flavicarpa Degener and P. incarnata. L. J. Exp. Bot., 46 : (288), 777-785.

SAS Institute (1998), SAS/STAT User's Guide. Release 6. 12. ed. Cary : SAS Institute Inc.

Sousa, J. S. I; Meletti, L. M. M. (1997), Maracujá: Espécies, variedades, cultivo. Piracicaba : FEALq. $179 \mathrm{pp}$.

Williams, J. G. K.; Kubelick, A. R.; Livak, K. J.; Rafalski, J. A. and Tingey, S. V. (1990), DNA polymorphisms amplified by arbitrary primers are useful as genetic markers. Nucleic Acids Res., 18, 6531-6535.

Received: December 26, 2001; Revised: August 01, 2002; Accepted: July 10, 2003. 